\title{
Potential Assessment of Oleaginous Fungi for Sustainable Biodiesel Production: Screening, Identification and Lipid Production Optimization
}

Ghada Youssef ( $\sim$ aminghada66@gmail.com )

Alexandria University https://orcid.org/0000-0002-1600-014X

Ahmed Elrefaey

Botany and Microbiology Department, Faculty of Science, Al-Azhar University, Assiut, Egypt.

\section{Samy El-Assar}

Botany and Microbiology Department, Faculty of Science, Alexandria University, Alexandria, 21431, Egypt

\section{Research}

Keywords: Oleaginous fungi, Promising fungal isolates, Maximize lipid accumulation, Biodiesel, Fatty acid profile

Posted Date: December 15th, 2020

DOI: https://doi.org/10.21203/rs.3.rs-127210/v1

License: (우 (i) This work is licensed under a Creative Commons Attribution 4.0 International License. Read Full License 


\section{Abstract}

The present work, aiming to exploit oleaginous fungi for biodiesel production. Ten fungal strains were isolated from two petroleum polluted soil samples and screened for their abilities to accumulate lipid. Lipid rich three species viz, Aspergillus terreus, Aspergillus niger and Aspergillus flavus were found to be the highest lipid producers. Potential isolates were identified at the species level by morphological (macroscopic and microscopic) examination and molecularly confirmed by using 18S rRNA gene sequencing. Improvement of lipid accumulation by optimization of various parameters of culture conditions. The results reported clearly that the most suitable medium conditions for highest lipid production (38.33\%) of Aspergillus terreus as the most potent lipid producer composed of $5 \%$ sucrose, $0.5 \mathrm{~g} / \mathrm{L}$ ammonium nitrate with initial $\mathrm{pH} 6.0$, after seven days of incubation in a static condition. The three promising fungal isolates have been taken for fatty acids analysis by gas chromatograph (GC) after transesterification. Fatty acid methyl esters (FAME) profile indicated the presence of higher saturated fatty acid fractions compared to polyunsaturated fatty acids. The total concentration of fatty acids was $107.98,38.29$, and $37.48 \mathrm{mg} / 100 \mathrm{~g}$ of lipid accumulated by $A$. terreus, A. niger and $A$. flavus, respectively. Gas chromatograph analysis of $A$. terreus lipid indicated that oleic acid (C18:1, 18.51\%) was the most abundant fatty acid, followed by stearic acid (C18:0,15.91\%) and Myristic acid (C14:0,14.64\%), respectively. Therefore, fatty acid profile of $A$. terreus has confirmed its potentiality as feedstock for producing lipid for biodiesel manufacturing.

\section{Introduction}

Massive consumption of fossil fuels has already caused serious concern over global warming caused by greenhouse gases emission (Campbell-Lendrum and Prüss-Ustün 2019; Matsakas et al. 2017). Biodiesel is the most efficient renewable and sustainable substitute for fossil diesel fuel that is focused on biomass (Mahlia et al. 2020). Biofuel offers an eco-friendly attractive alternative to fossil fuels (Khan and Hussain 2017; Nisar et al. 2017). Recently, research attention has been shifted to the biofuel production on a global scale from single cell oils (SCO) produced by oleaginous microorganisms (Meng et al. 2009; Papanikolaou 2019; Ramírez-castrillón et al. 2017; Tao et al. 2006). These oleaginous species have the ability to accumulate and store $20-25 \%$ of lipids of its total dry biomass (Athenaki et al. 2018; Hu et al. 2009), mostly consisting of triacylglycerols (TAG) that form the storage fraction of the cell. Microbial lipids (SCO) that are produced by oleaginous microorganisms and considered as a promising feedstock for biodiesel production including microalgae, bacteria, fungi, and yeasts (Bharti 2019; Cho and Park 2018; El-Kassas et al. 2016; El-Sheekh and Hamouda 2016; Hamouda et al. 2016; Hoekman et al. 2012; li et al. 2008; Meng et al. 2009; Subramaniam et al. 2010). Microbial oils have several advantages such as productivity is usually higher than the plants or vegetable oils, they can be effectively developed in bioreactors, have short life cycles, show rapid growth rates, easy genetic modifications for certain products, and light independency or other climatic varieties (Dourou et al. 2018; Sitepu et al. 2014).

Oleaginous filamentous fungi are an attractive source for biodiesel synthesis and suggested as a favorable feedstock for a sustainable biodiesel industry (Hoffmeister and Keller 2007; Papanikolaou and Aggelis 2011; Peng and Chen 2008; Reis et al. 2019; Zhao et al. 2008). Many fungal species are considered as SCO and able to accumulate lipids, including Aspergillus oryzae, Aspergillus awamori, Mortierella isabellina, Mortierella alliacea, Humicola lanuginose, Trichoderm a reesei, Penicillium commune, and Mucor circinelloides (Antonio et al. 2013; Bhanja et al. 2014; Hussein et al. 2017; Li et al. 2008; Magdum et al. 2015; Rossi et al. 2011; Shafiq and Ali 2017).

Lipid accumulation by oleaginous fungi using different renewable substrates such as glycerol (Papanikolaou and Aggelis 2002; Polburee 2015; Ramírez-castrillón et al. 2017; Rivaldi et al. 2017), molasses and whey (Bellou 2012; Economou et al. 2011a; Vieira 2014), wastes from food industry, agro industrial residues, lignocellulosic biomass, seed oils and wastewater (Babakur 2019; Chuppa-Tostain et al. 2018; Cuevas et al. 2020; Campos et al. 2020; Dourou et al. 2018; Economou et al. 2011b; Ekas et al. 2019; Shafiq and Chechan 2019; Tsegaye 2018a, 2018b; Yousuf 2010). Glucose is the carbon source most normally utilized to enhance the growth of oleaginous fungi and lipid accumulation (Ochsenreither et al. 2016; Saxena et al. 2008; Zhao et al. 2008).

The fatty acid profile of microbial lipids is quite similar to that of conventional vegetable oils (Papanikolaou 2012; Rude and Schirmer

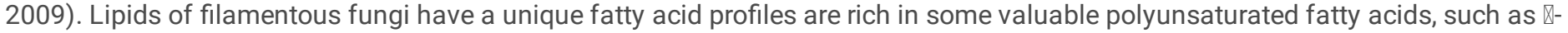
linoleic acid that cannot be synthesized by many other oleaginous microorganisms (Ratledge 2013; Subramaniam et al. 2010; Subhash and Mohan 2011). Gamma - linoleic acid (GLA; 18:3) is as an essential fatty acid in humans and has been reported to be effective for the prevention of a variety of diseases including cardiovascular diseases, rheumatoid arthritis, hyper-cholestromia, atopic eczema and asthma (Murad et al. 2010). Also, it was often utilized in dietary supplements and for infant nutrition (Huang et al. 2009).

Two main types of biofuels are biodiesel and ethanol which have become the most environment-friendly alternative fuels like petroleum, diesel and jet fuel for transportation (Wormslev 2016). Biodiesel is increasingly attracting worldwide attention due to the cost-effective 
and eco-friendly, as biodegradability; a decrease of sulfur and aromatic hydrocarbons content, which reduced their toxic emission of $\mathrm{CO}$, $\mathrm{CO}_{2}$ during fuel combustion (Demirbas 2008; Knothe 2008; Kotasthan 2017). Biodiesel involves the mixture of fatty acyl methyl/ethyl esters (FAMEs), obtained typically from transesterification of vegetable oil that can be used for existing conventional diesel engines regardless of its origin and feedstocks from which it is derived (Alptekin 2017; Patel et al. 2017).

The focus of the present work was to isolate, identify and characterize oleaginous fungal species from oily polluted soil samples, estimate the lipid content of these isolates, study the effects of physical and nutritional parameters to detect and maximize the accumulation of intracellular lipids of the promising fungal strains to enhance the quality of biodiesel. Finally, investigate the fatty acid methyl ester (FAME) composition after transesterification of fungal oil. According to the literature, fatty acids from the promising oleaginous isolated fungus are significant for biodiesel production.

\section{Materials And Methods}

\section{Samples collection and fungi isolation}

Ten fungal isolates were screened from two different oil-rich soil locations in the front of Moharam-Bek and Amrya gas stations which were polluted by petroleum products effluent in Alexandria, Egypt. Samples were collected in sterile containers and taken to the laboratory for analysis. Serial dilutions of the collected samples were carried out until $10^{-5}$ folds to isolate oleaginous fungi. One $\mathrm{ml}$ of the dilute was pour plated on Potato Dextrose Agar medium (PDA) supplemented with $2 \mathrm{~mL}$ of gentamicin and then incubated at $28^{\circ} \mathrm{C}$ for 3-6 days (Kumar et al. 2011). Morphological appearances of the inoculated plates were observed and distinct pure colonies were subcultured on PDA slants and stored at $4{ }^{\circ} \mathrm{C}$ for further study.

\section{Screening of oleaginous fungal isolates for lipid production}

Pure fungal isolates were cultured on basal medium (g/L): yeast extract $0.5, \mathrm{MgSO}_{4} .7 \mathrm{H}_{2} \mathrm{O} 0.4, \mathrm{KH}_{2} \mathrm{PO}_{4} 2.0, \mathrm{CaCl}_{2} 0.5, \mathrm{CuSO}_{4} 5 \mathrm{H}_{2} \mathrm{O} 0.05$, and $5 \%$ glucose $(\mathrm{w} / \mathrm{v})$, with initial $\mathrm{pH} 6.0$ to select the highest lipid producers. A portion of mycelium from PDA slant were transferred to a tube containing $10 \mathrm{~mL}$ sterilized distillated water and agitated then $0.5 \mathrm{~mL}$ of this spore suspension taken by micropipette and added to $250 \mathrm{~mL}$ conical flasks containing $50 \mathrm{~mL}$ of the basal medium and then incubated in $30^{\circ} \mathrm{C}$ for seven days under static condition. After incubation the culture fungal growth was harvested by filtration (Whatman no.1), and the mats biomass were collected and washed three times with distilled water to remove the medium residues. The biomass was dried in a hot air oven at $60^{\circ} \mathrm{C}$ until constant weight.

\section{Extraction of fugal lipid and determination of total lipid content}

The lipids were extracted from the screened fungal isolates dried biomass by the method of Bligh and Dyer method (1959) with slight modification using chloroform: methanol 2:1 (v/v). One hundred milligrams of the dried biomass was crushed with a mortar and pestle. Mixture of $10 \mathrm{~mL}$ of chloroform, and $5 \mathrm{~mL}$ of methanol were mixed, $8 \mathrm{~mL}$ from this mixture withdrew and added to a known amount of crushed dried mycelium then vortexed for 5 minutes. Saline solution $(7.3 \mathrm{~g}$ of $\mathrm{NaCl}, 10 \mathrm{~mL}$ of distillated water) was prepared, withdrew $2 \mathrm{ml}$ of the prepared saline solution then added to each sample tube (containing dried mycelium) then vertexing for 5 minutes. Samples centrifuged at $3000 \mathrm{rpm}$ for 15 minutes and the lower layer of methanol, water and $\mathrm{NaCl}$ was removed by Pasteur pipette, residual of solvent was dried then estimated gravimetrically $\mathrm{mg} / \mathrm{L}$ and determine the ratio of extracted lipids in compare to the cell dry weight (Magdum et al. 2015).

Percentage of lipid content $(\%)=$ weight of lipid $(\mathrm{g}) /$ weight of dried biomass $(\mathrm{g}) \times 100$

\section{Morphological and molecular identification of the most potent fungal isolates}

The promising lipid producers were kindly identified morphologically at the Mycological Center, Assiut University, Assiut, Egypt. Identification was performed considering some specific morphologic characteristics, such as colony diameter, color, texture appearance, and microscopic examination was done by lactophenol cotton blue staining including conidiophore, vesicle, metulae, phialides and conidia (Larone 2002).

The promising selected oleaginous fungi were molecularly identified based on the $18 \mathrm{~S}$ rRNA sequences. Fungal strains were cultivated on PDA medium at $28^{\circ} \mathrm{C}$ for 5 days. A small amount of the fresh culture was scraped and suspended in $100 \mu \mathrm{L}$ autoclaved distilled water in a sterile Eppendorf vial $\left(2 \mathrm{ml}\right.$ capacity) and boiled in a water bath at $100{ }^{\circ} \mathrm{C}$ for 15 minutes. The non-living fungal strain was sent to the Molecular Biology Research Unit, Assiut University, Egypt for DNA extraction using patho gene-spin DNA/RNA extraction kit provided by Intron Biotechnology Company, Korea. The (ITS) region of the rRNA gene was amplified by polymerase chain reaction (PCR)

Page $3 / 19$ 
at SolGent Company, Daejeon South Korea using two universal fungal primers ITS1 (forward) and ITS4 (reverse). Primers have the following composition: ITS1 (5' - TCC GTA GGT GAA CCT GCG G - 3'), and ITS4 (5'- TCC TCC GCT TAT TGA TAT GC -3'). The purified PCR product (amplicon) was reconfirmed using a size nucleotide marker (100 base pairs) by electrophoreses on $1 \%$ agarose gel. Then these bands were eluted and sequenced with the incorporation of dideoxynucleotides (dd NTPs) in the reaction mixture. Each sample was sequenced in the sense and antisense directions using ITS1 and ITS4 primers (White et al. 1990). Sequences were further analyzed using Basic Local Alignment Search Tool (BLAST) from the National Center of Biotechnology Information (NCBI) website. The phylogenetic tree was constructed by the neighbour-joining program in MEGA 5.05 software.

\section{Optimization of culture conditions to maximize lipid production}

To enhance biodiesel production from the tested fungal strains, the influence of the studied nutritional and environmental parameters on the fungal growth and lipid production are discussed under static condition for the promising fungal isolates ( $A$. terreus, $A$. niger and $A$. flavus).

\section{Effect of carbon and nitrogen sources on lipid production}

The effect of different carbon sources on the lipid production was studied using the basal culture medium supplemented with (5\%) glucose as a control. An equimolar amount of eight different carbon sources were tested as fructose, lactose, sucrose, maltose, dextrose, starch, wheat bran, and corn. Also for nitrogen source, yeast extract was replaced on equal nitrogen bases $(0.5 \mathrm{~g} / \mathrm{L})$ by six different nitrogen sources as ammonium nitrate, sodium nitrate, peptone, ammonium acetate, casein, and soybean one at a time.

\section{Effect of initial pH and incubation period on lipid production}

The initial $\mathrm{pH}$ of the culture medium was adjusted with $1 \mathrm{~N} \mathrm{HCl}$ or $1 \mathrm{~N} \mathrm{NaOH}$ before autoclaving at different values ranging from 4 to 9 under static condition for 7 days. The effect of incubation period was detected at different time intervals 3, 5, 7 and 9 days.

\section{Effect of incubation temperature on lipid production}

The effect of different incubation temperatures was evaluated as following $20^{\circ} \mathrm{C}, 25^{\circ} \mathrm{C}, 30^{\circ} \mathrm{C}, 35^{\circ} \mathrm{C}$, and $40^{\circ} \mathrm{C}$ for 7 days.

\section{Methylation of lipid and transesterification}

The transesterification reaction of the obtained tested lipids was performed according to Radwan (1978) with slight modification. The lipid sample $(5 \mathrm{mg})$ is dissolved in benzene $(2 \mathrm{ml})$ in a test tube fitted with a condenser, and $1 \%$ sulfuric acid in methanol $(2.0 \mathrm{ml})$ is added, close the tube well and place in water bath at $90{ }^{\circ} \mathrm{C}$ for an hour and half. Cool, add $8 \mathrm{~mL}$ water and $5 \mathrm{~mL}$ petroleum ether shake and separate out the ethereal layer in a dry tube.

\section{Gas chromatography (GC)}

Gas chromatographic analysis of FAMEs for promising fungal isolates were performed using Hewlett Packard (HP) 6890 GC system at Central Laboratories of General Health Institute, Alexandria, Egypt.

\section{Results And Discussion}

\section{Screening of different oleaginous fungal strains for their lipid production}

Ten locally fungal isolates were obtained, five from Moharam-Bek and five from Amrya oily polluted soil gas stations, Alexandria, Egypt. The selected fungal isolates were tested for their growth and lipid accumulation under static condition (Table 1). The highest lipid value (24.14\%) was achieved by a brown fungus, isolate (F1) from Moharam-Bek station, followed by a black fungus, isolate (F6) from Amrya station (12.32\%) and olive green fungus, isolate (F2) from Moharam-Bek station (6.25\%). Qiao et al. (2018) revealed that the highest yield and the maximum lipid content produced by Mucor circinelloides in static condition. These results were congruent with Ali and ElGhonemy (2014); Kirrolia et al. (2012); Pandey et al. (2000) who reported that lipid accumulation was higher in the static condition as compared to that generated in shaking condition. Shafiq and Ali (2017); Somasekhar et al. (2003) indicated that many species of oleaginous fungi are able to accumulate significant amounts of intracellular lipid. The stored intracellular lipid content is utilized to maintain generations of cells leading to the production of lipid-free biomass (Park et al. 1990; Subhash and Mohan 2014). This phenomenon is known as lipid turnover (Fakas et al. 2007; Huang 2009; Wu et al. 2010). 
Table 1

Screening of different fungal isolates for their oleaginicity and determination of fungal biomass.

\begin{tabular}{|lllll|}
\hline Isolate No./Soil source & Colony colour & $\begin{array}{l}\text { Dry biomass } \\
(\mathbf{g} / \mathbf{5 0} \mathbf{~ m L})\end{array}$ & Lipid concentration $(\mathbf{g} / \mathbf{L})$ & $\begin{array}{l}\text { Lipid content } \\
(\%)\end{array}$ \\
\hline F1/(MS) & Brown & 0.29 & 1.40 & 24.14 \\
\hline F2/(MS) & Green & 0.24 & 0.30 & 6.25 \\
\hline F3/(MS) & Black & 0.20 & 0.20 & 5.00 \\
\hline F4/(MS) & Black & 0.21 & 0.08 & 1.90 \\
\hline F5/(MS) & Green & 0.18 & 0.10 & 2.78 \\
\hline F6/(AS) & Black & 0.28 & 0.69 & 12.32 \\
\hline F7/(AS) & Brown & 0.30 & 0.22 & 3.67 \\
\hline F8/(AS) & Green & 0.20 & 0.15 & 3.75 \\
\hline F9/(AS) & Brown & 0.30 & 0.32 & 5.33 \\
\hline F10/(AS) & Green & 0.17 & 0.12 & 3.53 \\
\hline MS = Moharam-Bek Station, AS = Amrya Station & & \\
\hline
\end{tabular}

\section{Morphological and molecular identification of the promising fungal isolates}

The promising fungal isolates were recorded as potent lipid producers. They are identified morphologically (macroscopic characteristics and microscopic examination) at Assuit University Mycological Center (AUMC), Egypt. Sample coded ARS-1 was Aspergillus niger, (ARS2) Aspergillus terreus, and (ARS-3) Aspergillus flavus as shown in Fig. 1.

Molecular identification of fungi and similarities with closely related fungal strains were done using Basic Local Alignment Search Tool (BLAST). The 18S rRNA sequence and its homologous sequences were analyzed using MegAlign (DNA Star) software version 5.05. Phylogenetic tree was constructed after alignment with the related strains with a percentage of similarity (Fig. 2).

\section{Optimization of culture conditions for the highest lipid production}

Optimization of the culture conditions was a significant strategy to enhance the lipid accumulation with economical cost efficiency (Jiru et al. 2017).

\section{Effect of different carbon sources on lipid production}

The present results (Table 2) estimated that the maximum lipid production (31.50\%) of $A$. terreus was achieved in presence of sucrose as a sole carbon source, while wheat bran led to the highest dry biomass $(0.48 \mathrm{~g} / 50 \mathrm{~mL})$. Glucose was the suitable carbon source for $A$. niger with maximum lipid content and highest biomass $(12.32 \%, 0.28 \mathrm{~g} / 50 \mathrm{~mL})$ followed by lactose as a preferred carbon source yielding a maximum lipid productivity (8.33\%) for A. flavus. According to Abu-Elreesh and Abd- El-Haleem (2014); Al-Hawash et al. (2018); Baqir et al. (1997); Carvalho et al. (2018); El-Haj et al. (2015); Assawah et al. (2020) who estimated that glucose served as the best carbon source yielding a maximum lipid production for $A$. spp. which agree with our study on $A$. niger. On the other hand, Abdelhamid et al. (2019) suggested that maximum lipid accumulation reached $34.92 \%$ for Penicillium commune in presence of xylose. 
Table 2

Effect of different carbon sources on promising fungal strains lipid production.

\begin{tabular}{|c|c|c|c|c|c|c|c|c|c|}
\hline \multirow{2}{*}{$\begin{array}{l}\text { Fungal } \\
\text { strain } \\
\text { Carbon } \\
\text { source }\end{array}$} & \multicolumn{3}{|l|}{ A. niger } & \multicolumn{3}{|l|}{ A. flavus } & \multicolumn{3}{|l|}{ A. terreus } \\
\hline & $\begin{array}{l}\text { Biomass } \\
(\mathrm{g} / \\
50 \mathrm{~mL})\end{array}$ & $\begin{array}{l}\text { Lipid } \\
\text { concentration } \\
\text { (g/L) }\end{array}$ & $\begin{array}{l}\text { Lipid } \\
\text { content } \\
\text { (\%) }\end{array}$ & $\begin{array}{l}\text { Biomass } \\
(\mathrm{g} / \\
50 \mathrm{~mL})\end{array}$ & $\begin{array}{l}\text { Lipid } \\
\text { concentration } \\
\text { (g/L) }\end{array}$ & $\begin{array}{l}\text { Lipid } \\
\text { content } \\
(\%)\end{array}$ & $\begin{array}{l}\text { Biomass } \\
(\mathrm{g} / \\
50 \mathrm{~mL})\end{array}$ & $\begin{array}{l}\text { Lipid } \\
\text { concentration } \\
\text { (g/L) }\end{array}$ & $\begin{array}{l}\text { Lipid } \\
\text { content } \\
(\%)\end{array}$ \\
\hline Glucose & 0.28 & 0.69 & 12.32 & 0.24 & 0.30 & 6.25 & 0.29 & 1.40 & 24.14 \\
\hline Fructose & 0.22 & 0.36 & 8.18 & 0.22 & 0.34 & 7.73 & 0.24 & 1.26 & 26.25 \\
\hline Lactose & 0.11 & 0.15 & 6.82 & 0.24 & 0.40 & 8.33 & 0.41 & 1.69 & 20.61 \\
\hline Sucrose & 0.14 & 0.22 & 7.86 & 0.30 & 0.29 & 4.83 & 0.20 & 1.26 & 31.50 \\
\hline Maltose & 0.27 & 0.18 & 3.33 & 0.26 & 0.10 & 1.92 & 0.22 & 0.32 & 7.27 \\
\hline Dextrose & 0.24 & 0.49 & 10.21 & 0.29 & 0.38 & 6.55 & 0.38 & 1.66 & 21.84 \\
\hline Starch & 0.20 & 0.30 & 7.5 & 0.11 & 0.15 & 6.82 & 0.12 & 0.29 & 12.08 \\
\hline $\begin{array}{l}\text { Wheat } \\
\text { bran }\end{array}$ & 0.21 & 0.15 & 3.57 & 0.21 & 0.15 & 3.57 & 0.48 & 0.72 & 7.50 \\
\hline Corn & 0.08 & 0.10 & 6.25 & 0.17 & 0.07 & 2.06 & 0.29 & 1.04 & 17.93 \\
\hline
\end{tabular}

\section{Effect of different nitrogen sources on lipid production}

The results as shown in Table 3 revealed that the highest values for growth biomass and lipid content $(0.24 \mathrm{~g} / 50 \mathrm{~mL}$ and $38.33 \%)$ by $A$. terreus were achieved in presence of ammonium nitrate. The favorable nitrogen source for $A$. flavus was sodium nitrate yielding maximum lipid production (16.84\%), while peptone led to the highest dry biomass $(0.42$ and $0.26 \mathrm{~g} / 50 \mathrm{~mL})$ for $A$. niger and $A$. flavus, respectively. On the hand, yeast extract was the best nitrogen source for $A$. niger yielding maximum lipid productivity (12.32\%). These data were congruent with Abu-Elreesh and Abd-El-Haleem (2014) reported that yeast extract was the best nitrogen source for Aspergillus niger. Ramírez-Castrillón et al. (2017); Xing et al. (2012) with disagreement with these results reported that ammonium sulfate was shown to be the most suitable nitrogen source. In contrast, Abdelhamid et al. (2019) proved the maximum lipids production (43.06\%) for Penicillium commune in presence of peptone.

Table 3

Effect of various nitrogen sources on promising fungal strains lipid production.

\begin{tabular}{|c|c|c|c|c|c|c|c|c|c|}
\hline \multirow{2}{*}{$\begin{array}{l}\begin{array}{l}\text { Fungal } \\
\text { strain }\end{array} \\
\text { Nitrogen } \\
\text { sources }\end{array}$} & \multicolumn{3}{|l|}{ A. niger } & \multicolumn{3}{|l|}{ A. flavus } & \multicolumn{3}{|l|}{ A. terreus } \\
\hline & $\begin{array}{l}\text { Biomass } \\
(\mathrm{g} / \\
50 \mathrm{~mL})\end{array}$ & $\begin{array}{l}\text { Lipid } \\
\text { concentration } \\
\text { (g/L) }\end{array}$ & $\begin{array}{l}\text { Lipid } \\
\text { content } \\
\text { (\%) }\end{array}$ & $\begin{array}{l}\text { Biomass } \\
(\mathrm{g} / \\
50 \mathrm{~mL})\end{array}$ & $\begin{array}{l}\text { Lipid } \\
\text { concentration } \\
\text { (g/L) }\end{array}$ & $\begin{array}{l}\text { Lipid } \\
\text { content } \\
(\%)\end{array}$ & $\begin{array}{l}\text { Biomass } \\
(\mathrm{g} / \\
50 \mathrm{~mL})\end{array}$ & $\begin{array}{l}\text { Lipid } \\
\text { concentration } \\
\text { (g/L) }\end{array}$ & $\begin{array}{l}\text { Lipid } \\
\text { content } \\
(\%)\end{array}$ \\
\hline $\begin{array}{l}\text { Ammonium } \\
\text { nitrate }\end{array}$ & 0.38 & 0.66 & 8.68 & 0.11 & 0.22 & 10.00 & 0.24 & 1.84 & 38.33 \\
\hline $\begin{array}{l}\text { Sodium } \\
\text { nitrate }\end{array}$ & 0.26 & 0.48 & 9.23 & 0.19 & 0.64 & 16.84 & 0.23 & 1.69 & 36.74 \\
\hline Peptone & 0.42 & 0.55 & 6.55 & 0.26 & 0.38 & 7.31 & 0.21 & 0.79 & 18.81 \\
\hline $\begin{array}{l}\text { Ammonium } \\
\text { acetate }\end{array}$ & 0.11 & 0.21 & 9.55 & 0.20 & 0.35 & 8.75 & 0.10 & 0.40 & 20.00 \\
\hline Casein & 0.20 & 0.33 & 8.25 & 0.10 & 0.28 & 14.00 & 0.19 & 0.61 & 16.05 \\
\hline $\begin{array}{l}\text { Yeast } \\
\text { extract }\end{array}$ & 0.28 & 0.69 & 12.32 & 0.24 & 0.40 & 8.33 & 0.20 & 1.26 & 31.50 \\
\hline Soybean & 0.19 & 0.33 & 8.68 & 0.10 & 0.23 & 11.50 & 0.18 & 1.11 & 30.83 \\
\hline
\end{tabular}


The external pH of the medium was an important environmental factor affecting plasma membrane permeability, metabolic activity, and cell growth as reported by Amanullah et al. (2001); Minhas et al. (2016). As illustrated in Table 4 it was observed that the highest values for growth biomass and lipid production $(0.24 \mathrm{~g} / 50 \mathrm{ml}, 38.33 \%)$ and $(0.19 \mathrm{~g} / 50 \mathrm{ml}, 16.84 \%)$ at $\mathrm{pH} 6$ for $A$. terreus and $A$. flavus, respectively. In this regard, Sukrutha et al. (2014) estimated that the maximum lipid productivity was achieved by Cunninghamella blakesleeana at $\mathrm{pH}$ 6. The initial medium $\mathrm{pH} 7$ was the optimum value for maximum lipid production (14.17\%) by A. niger. The present data for $A$. niger was in line with that investigated by Abdelhamid et al. (2019) as the maximum lipid yield (33.16\%) by Penicillium commune at pH 7. Comparable results were estimated by Ali et al. (2017); Ali and El-Ghonemy (2014); Jiru et al. (2017); Ruan et al. (2014) who recorded that $\mathrm{pH}$ values ranging between 5 and 6 were found to be the suitable $\mathrm{pH}$ range for most oleaginous fungal growth and lipid production.

Table 4

Effect of initial $\mathrm{pH}$ on promising fungal strains lipid production.

\begin{tabular}{|c|c|c|c|c|c|c|c|c|c|}
\hline \multirow{2}{*}{$\begin{array}{l}\text { Fungal } \\
\text { strain } \\
\text { pH } \\
\text { value }\end{array}$} & \multicolumn{3}{|l|}{ A. niger } & \multicolumn{3}{|l|}{ A. flavus } & \multicolumn{3}{|l|}{ A. terreus } \\
\hline & $\begin{array}{l}\text { Biomass } \\
(\mathrm{g} / \\
50 \mathrm{~mL})\end{array}$ & $\begin{array}{l}\text { Lipid } \\
\text { concentration } \\
\text { (g/L) }\end{array}$ & $\begin{array}{l}\text { Lipid } \\
\text { content } \\
\text { (\%) }\end{array}$ & $\begin{array}{l}\text { Biomass } \\
(\mathrm{g} / \\
50 \mathrm{~mL})\end{array}$ & $\begin{array}{l}\text { Lipid } \\
\text { concentration } \\
(\mathrm{g} / \mathrm{L})\end{array}$ & $\begin{array}{l}\text { Lipid } \\
\text { content } \\
(\%)\end{array}$ & $\begin{array}{l}\text { Biomass } \\
(\mathrm{g} / \\
50 \mathrm{~mL})\end{array}$ & $\begin{array}{l}\text { Lipid } \\
\text { concentration } \\
(\mathrm{g} / \mathrm{L})\end{array}$ & $\begin{array}{l}\text { Lipid } \\
\text { content } \\
(\%)\end{array}$ \\
\hline 4 & 0.08 & 0.10 & 6.25 & 0.08 & 0.12 & 7.51 & 0.15 & 0.25 & 8.33 \\
\hline 5 & 0.10 & 0.17 & 8.50 & 0.14 & 0.39 & 13.93 & 0.17 & 0.94 & 27.65 \\
\hline 6 & 0.28 & 0.69 & 12.32 & 0.19 & 0.64 & 16.84 & 0.24 & 1.84 & 38.33 \\
\hline 7 & 0.24 & 0.68 & 14.17 & 0.15 & 0.42 & 14.02 & 0.21 & 1.22 & 29.04 \\
\hline 8 & 0.24 & 0.52 & 10.83 & 0.11 & 0.22 & 10.00 & 0.19 & 0.72 & 18.95 \\
\hline 9 & 0.13 & 0.14 & 5.38 & 0.07 & 0.09 & 6.43 & 0.13 & 0.21 & 8.08 \\
\hline
\end{tabular}

\section{Influence of incubation period on lipid production}

Incubation period has an observable effect on biomass lipid production. Lipid content of each strain differs depending upon its specific growth rate. In the current study, the lipid accumulation and dry biomass increased gradually during the first seven days of incubation and reached its maximum values $(38.33 \%, 0.24 \mathrm{~g} / 50 \mathrm{~mL})$ and $(16.84 \%, 0.19 \mathrm{~g} / 50 \mathrm{~mL})$ at the 7 th day of incubation for $A$. terreus and $A$. flavus, respectively (Table 5). These results are in accordance with those reported by Sukrutha et al. (2014), who investigated the maximum lipid production was $28 \%$ after 6 days in static incubation of Cunninghamella blakesleeana. The fifth day of incubation was the optimum incubation period of $A$. nigeryielding maximum lipid production (18.67\%). Our results are in line with that detected by Ali et al. (2017); Kumar and Banerjee (2013), the maximum lipid production by Aspergillus spp. was achieved after 5 days of incubation. Also, study on Penicillium commune recorded the maximum lipid production (46.36\%) after 5th day of incubation (Abdelhamid et al. 2019).

Table 5

Effect of different incubation periods on promising fungal strains lipid production.

\begin{tabular}{|c|c|c|c|c|c|c|c|c|c|}
\hline \multirow{2}{*}{$\begin{array}{l}\text { Fungal } \\
\text { strain } \\
\text { Incubation } \\
\text { period } \\
\text { (day) }\end{array}$} & \multicolumn{3}{|l|}{ A. niger } & \multicolumn{3}{|l|}{ A. flavus } & \multicolumn{3}{|l|}{ A. terreus } \\
\hline & $\begin{array}{l}\text { Biomass } \\
(\mathrm{g} / \\
50 \mathrm{~mL})\end{array}$ & $\begin{array}{l}\text { Lipid } \\
\text { concentration } \\
\text { (g/L) }\end{array}$ & $\begin{array}{l}\text { Lipid } \\
\text { content } \\
(\%)\end{array}$ & $\begin{array}{l}\text { Biomass } \\
(\mathrm{g} / \\
50 \mathrm{~mL})\end{array}$ & $\begin{array}{l}\text { Lipid } \\
\text { concentration } \\
\text { (g/L) }\end{array}$ & $\begin{array}{l}\text { Lipid } \\
\text { content } \\
\text { (\%) }\end{array}$ & $\begin{array}{l}\text { Biomass } \\
(\mathrm{g} / \\
50 \mathrm{~mL})\end{array}$ & $\begin{array}{l}\text { Lipid } \\
\text { concentration } \\
\text { (g/L) }\end{array}$ & $\begin{array}{l}\text { Lipid } \\
\text { content } \\
\text { (\%) }\end{array}$ \\
\hline 3 & 0.06 & 0.1 & 8.33 & 0.09 & 0.12 & 6.67 & 0.06 & 0.11 & 9.17 \\
\hline 5 & 0.15 & 0.56 & 18.67 & 0.18 & 0.48 & 13.33 & 0.16 & 0.75 & 23.44 \\
\hline 7 & 0.24 & 0.68 & 14.17 & 0.19 & 0.64 & 16.84 & 0.24 & 1.84 & 38.33 \\
\hline 9 & 0.28 & 0.31 & 5.54 & 0.19 & 0.37 & 9.74 & 0.23 & 1.33 & 28.91 \\
\hline
\end{tabular}

\section{Influence of incubation temperature on lipid production}


In the case of studying the effect of incubation temperature in the present survey, the highest fungal biomass and lipid productivity were reported at $30{ }^{\circ} \mathrm{C}$ for the all promising fungal strains, A. terreus, $A$. niger and $A$. flavus. The maximum lipid production for $A$. terreus as the most potent lipid producer reached $38.33 \%$ at incubation temperature of $30^{\circ} \mathrm{C}$. The results are in accordance with those recorded by Ali \& El-Ghonemy (2014); Carlile et al. (2001); Li et al. (2008); Subhash and Mohan (2014). Patel and Desai (2019) estimated that the incubation temperature of $32^{\circ} \mathrm{C}$ was the optimum value for extracellular enzyme production for polysaccharide degradation and lipid accumulation of fungi. While, Abdelhamid et al. (2019) reported the maximum lipid accumulation percentage (41.18\%) for Penicillium commune was estimated at $26^{\circ} \mathrm{C}$ incubation temperature.

\section{Fatty acid methyl ester (FAME) profile and gas chromatographic (GC) analysis of promising lipid producers}

The fatty acid profile of the lipid samples was estimated by converting the fatty acids (FAs) to fatty acid methyl esters (FAMEs) after transesterification. The transesterified fatty acids were identified using GC analysis. The lipid profiles are differing qualitatively and quantitatively among all tested fungi. However, oleic acid and linoleic acid were absent in the lipids of $A$. niger. The presented data (Fig. 3) indicated the presence of a high fraction of saturated FAs than unsaturated FAs which is considered a potential feature to detect the fuel quality of fungal based diesel (Dai et al. 2007; Shafiq 2017; Shafiq and Chechan 2019; Subhash and Mohan 2011; Subhash and Mohan 2014; Zheng et al. 2012). This composition is quite in agreement to the commonly used vegetable oil feedstock for biodiesel such as soybean, rapeseed, palm and sunflower (Christophe et al. 2012). The total concentration of FAs was 107.98, 38.29, and $37.48 \mathrm{mg} / 100 \mathrm{~g}$ of lipid generated by Aspergillus terreus, Aspergillus niger and Aspergillus flavus, respectively.

\section{Fatty acid composition of the potent fungal lipid producer}

The fatty acid composition of Aspergillus terreus as the most potent fungal isolate was cited in (Fig. 4, Table 6). The GC- profile indicated the presence of high proportion of long-chain FAs, composed of a mixture of saturated FAs such as stearic acid (C18:0) 15.91\%; myristic acid (C14:0) 14.64\%; palmitic acid (C16:0) 10.92\%; tridecanoic acid (C13:0) 10.61\%; and pentadecenoic acid (C15:0) 8.78\%. Limited percentage of mono-and polyunsaturated FAs was estimated such as oleic acid (C18:1) 18.51\%; 14, pentadecenoic acid (C15:1) 4.59\% as monounsaturated fatty acid (MUFA) and linoleic acid (C18:2) 13.20\% as a polyunsaturated fatty acid (PUFA). A higher percent of saturated fatty acid (SFA) $(60.86 \%)$ than unsaturated fatty acid $(36.30 \%)$ was estimated. These results are in agreement with Farias et al. (2018) who reported that a higher percent of saturated fatty acid (70.7\%) than unsaturated fatty acid (29.3\%). The total SFA content (60.86\%) was higher than other plant oils like palm oil (44\%), Jatropha oil (21.52\%) and soyabean oil (15\%) (Vyas \& Chhabra 2017) which indicates its high quality biodiesel.

Table 6

Lipid profile and fatty acid concentration of Aspergillus terreus.

\begin{tabular}{|llll|}
\hline Carbon number: Number of double bond & Fatty acid & Fatty acid (\%) & Concentration of FA (mg/100 $\mathbf{~})$ \\
\hline C12:0 & Lauric acid & 2.84 & 3.06 \\
\hline C13:0 & Tridecanoic acid & 10.61 & 11.46 \\
\hline C14:0 & Myristic acid & 14.64 & 15.81 \\
\hline C15:1 & 14, Pentadecenoic acid & 4.59 & 4.96 \\
\hline C15:0 & Pentadecenoic acid & 8.78 & 9.48 \\
\hline C16:0 & Palmitic acid & 10.92 & 11.79 \\
\hline C18:2 & Linoleic acid & 13.20 & 14.25 \\
\hline C18:1 & Oleic acid & 18.51 & 19.99 \\
\hline C18:0 & Stearic & 15.91 & 17.18 \\
\hline Total concentration of FA in $\mathrm{mg} / 100 \mathrm{~g}$ of Lipid & & 107.98 \\
\hline
\end{tabular}

In the current study, a higher number of saturated fatty acids than polyunsaturated fatty acids was observed that indicates the fungal oil obtained has properties similar to those of biodiesel, which confirms its superior biodiesel quality (Babakura et al. 2019; Gadallah and 
Abd-El-Haleem 2014; Wu et al. 2010). The presence of long chain fatty acids of FAME profile improves biodiesel properties, and hence, confirms high fuel efficiency (Çiçek and Yalçın 2013; Dai et al. 2007; Vicente et al. 2009; Zheng et al. 2012; Ziino et al. 1999).

\section{Conclusion}

Experimental data revealed the goals of the work, promising fungal isolates Aspergillus terreus, Aspergillus niger and Aspergillus flavus exhibited satisfactory lipid accumulation and constructed for biodiesel production. Optimization of cultural conditions for maximum lipid production (38.33\%) was achieved on the seventh day of growth at $30{ }^{\circ} \mathrm{C}$ incubation temperature in a static condition, using $5 \%$ sucrose, $0.5 \mathrm{~g} / \mathrm{L}$ ammonium nitrate with initial pH 6.0 for Aspergillus terreus as a highest lipid producer. FAME profile indicated the presence of higher saturated fatty acid fraction compared to unsaturated fatty acids of the tested fungal species. The total concentration of fatty acids was $107.98,38.29$, and $37.48 \mathrm{mg} / 100 \mathrm{~g}$ of lipid accumulated by $A$. terreus, $A$. niger and $A$. flavus, respectively. Gas chromatograph analysis of $A$. terreus lipid as the potent fungal strain revealed that oleic acid (C18:1, 18.51\%) was the most abundant fatty acid, followed by stearic acid (C18:0, 15.91\%) and Myristic acid (C14:0, 14.64\%). Therefore, fatty acid profile of $A$. terreus has confirmed its potentiality as a new commercial biodiesel feedstock.

\section{Declarations}

\section{Ethics approval and consent to participate:}

Not applicable.

\section{Consent for publication:}

Not applicable

Availability of data and materials:

Not applicable.

\section{Competing interests:}

No potential conflicts of interest were reported by the authors.

\section{Funding:}

The authors did not receive support from any organization for the submitted work.

\section{Authors' contributions:}

All authors contributed to the study conception and design. Material preparation was performed by (Ahmed M. Elrefaey), data collection and analysis were performed by (Ghada A. Youssef \& Ahmed M. Elrefaey).All authors contributed to the writing of this article. All authors read and approved the final manuscript.

\section{Acknowledgements:}

Not applicable.

\section{Disclosure statement:}

No potential conflicts of interest were reported by the authors.

\section{References}

1. Abdelhamid S, Hussein A, Asker M, El Sayed O, Mohamed S (2019) Optimization of culture conditions for biodiesel production from Egyptian isolate Penicillium commune NRC2016. Bulletin of the National Research Centre 43: 15-23.

2. Abu-Elreesh G, Abd-El-Haleem D (2014) Promising oleaginous filamentous fungi as biodiesel feed stocks: screening and identification. European Journal of Experimental Biology 4(1): 567-582. 
3. Al-Hawash AB, Li S, Zhang X, Zhang X, Ma F (2018) Productivity of Y-linoleic acid by oleaginous fungus Cunninghamella echinulata using a pulsed high magnetic field. Food Bioscience 21: 1-7.

4. Ali TH, El-Gamal MS, El-Ghonemy DH, Awad GE, Tantawy AE (2017) Improvement of lipid production from an oil-producing filamentous fungus, Penicillium brevicompactum NRC 829, through central composite statistical design. Annals of Microbiology 67(9): 601-613.

5. Ali TH, El-Ghonemy DH (2014) Optimization of culture conditions for the highest lipid production from some oleaginous fungi for biodiesel preparation. Asian Journal of Applied Sciences 2: 600-609.

6. Alptekin, E (2017) Emission, injection and combustion characteristics of biodiesel and oxygenated fuel blends in a common rail diesel engine. Energy 119 (15): 44-52.

7. Amanullah A, McFarlane CM, Emery AN, Nienow AW (2001) Scale-down model to simulate spatial pH variations in large-scale bioreactors. Bioethanol Bioengineer 73: 390-399.

8. Antonio BS, Abd RH, Solchenbach S, Montoya A, Rollon AP, Siringan MA, Abbas A (2013) Biodiesel-Derived Crude Glycerol for the Fungal Production of Lovastatin. Conference Paper. Engineers Australia pp.657-662.

9. Assawah SM, El-Gadidy M, Saad-Allah Kh, El-Badry A (2020) Evaluation of the oleaginous Rhizopus stolonifer capability for lipid production using agricultural wastes as cheap nutritional sources for biodiesel production. The Egyptian Journal of Experimental Biology 16(1): 35-48.

10. Athenaki M, Gardeli C, Diamantopoulou P, Tchakouteu SS, Sarris D, Philippoussis A, Papanikolaou S (2018) Lipids from yeasts and fungi: physiology, production and analytical considerations. Journal of Applied Microbiology 124(2): 336-367.

11. Babakura M, Yelwa JM, Ibrahim A, Aliyu BM, Yahaya JY, Umar JB, Auwal MM, Ogabidu AO (2019) Synthesis and characterization of biodiesel from Khaya senegalensis seed oil using heterogeneous catalyst. International Journal of Science and Management Studies 2(4): 101-107.

12. Baqir SN, Hashmi K, Khan AF, Sheikh D, Mehmood AZ (1997) Production of lipids by fermentation preliminary report. Journal of Islamic Academy of Sciences 10 (1):13-18.

13. Bellou S, Moustogianni A, Makri A, Aggelis S (2012) Lipids containing polyunsaturated fatty acids synthesized by zygomycetes grown on glycerol. Applied Biochemistry and Biotechnology 166:146-158.

14. Bhanja AD, Minde GP, Magdum SS, Kalyanraman V (2014) Comparative studies of oleaginous fungal strains (Mucor circinelloides and Trichoderma reesei) for effective wastewater treatment and Bio-Oil production. Biotechnology Research International 7: 1-7.

15. Bharti RK, Katiyar R, Dhar DW, Prasanna R, Tyagi R (2019) In situ transesterification and prediction of fuel quality parameters of biodiesel produced from Botryococcus sp. MCC31. Biofuels 1-10. doi.org/10.1080/17597269.2019.1594592.

16. Bligh EG, Dyer WJ (1959) A rapid method of total lipid extraction and purification. Canadian Journal of Biochemistry and Physiology37: 911-917.

17. Campbell-Lendrum D, Prüss-Ustün A (2019) Climate change, air pollution and noncommunicable diseases. Bulletin of the World Health Organization 97: 160-161.

18. Campos DA, Gómez-García R, Vilas-Boas AA, Madureira AR, Pintado MM (2020) Management of fruit industrial by-products-a case study on circular economy approach. Molecules 25(2): 320.

19. Carlile MJ, Watkinson SC, Graham WG (2001) The fungi, $2^{\text {nd }}$ edn. Academic, San Diego.

20. Carvalho AK, Bento HB, Izário Filho HJ, de Castro HF (2018) Approaches to convert Mucor circinelloides lipid into biodiesel by enzymatic synthesis assisted by microwave irradiations. Renew Energy 125: 747-754.

21. Cho HU, Park JM (2018) Biodiesel production by various oleaginous microorganisms from organic wastes. Bioresource Technology 256: 502-508.

22. Christophe G, Kumar V, Nouaille R, Gaudet G, Fontanille P, Pandey A, Larroche C (2012) Recent developments in microbial oils production: a possible alternative to vegetable oils for biodiesel without competition with human food?. Brazilian Archives of Biology and Technology 55(1): 29-46.

23. Chuppa-Tostain G, Hoarau J, Watson M, Adelard L, Shum Cheong Sing A, Caro Y, Grondin I, Bourven I, Francois JM, Girbal-Neuhauser E (2018) Production of Aspergillus niger biomass on sugarcane distillery wastewater: Physiological aspects and potential for biodiesel production. Fungal Biology and Biotechnology 5: 1-12.

24. Çiçek F, Yalçın E (2013) Fungal lipid production and usability in biodiesel production (Fungal lipid üretimi ve biyodizelüretiminde kullanılabilirliği). Turkish Journal of Biochemistry 38(2): 193-199.

Page $10 / 19$ 
25. Cuevas M, Saleh M, García-Martín J, Sánchez S (2020) Acid and enzymatic fractionation of olive stones for ethanol production using Pachysolen tannophilus. Processes 8: 195.

26. Dai C, Tao J, Xie F, Dai Y (2007) Biodiesel generation from oleaginous yeast Rhodotorula glutinis with xylose assimilating capacity. African Journal of Biotechnology 6(18): 2130-2134.

27. Demirbas A (2008) Biodiesel. In: Demirbas A (ed) A realistic fuel alternative for diesel engines. Springer, London, pp 39-64

28. Dourou M, Aggeli D, Papanikolaou S, Aggelis G (2018) Critical steps in carbon metabolism affecting lipid accumulation and their regulation in oleaginous microorganisms. Applied Microbiology and Biotechnology. 102: 2509-2523.

29. Economou CN, Aggelis G, Pavlou S, Vayenas DV (2011a) Modelling of single-cell oil production under nitrogen limited and substrate inhibition conditions. Biotechnology and Bioengineering 108: 1049-1055.

30. Economou CN, Aggelis G, Pavlou S, Vayenas DV (2011b) Single cell oil production from rice hulls hydrolysate. Bioresource Technology 102: 9737-9742.

31. Ekas H, Deaner M, Alper HS (2019) Recent advancements in fungal-derived fuel and chemical production and commercialization. Current Opinion in Biotechnology 57: 1-9.

32. El-Haj M, Olama Z, Holail H (2015) Biodiversity of oleaginous microorganisms in the Lebanese environment. International Journal of Current Microbiology and Applied Sciences 4(5): 950-961.

33. El-Kassas HY, Mohammady NG, El-Sayed HS, ELSherbiny BA (2016) Growth and biochemical variability of complete and lipid extracted Chlorella species (application for Artemia franciscana feeding). Rendiconti Lincei 27(4):761-74.

34. El-Sheekh MM, Hamouda RA (2016) Lipids extraction from the green alga Ankistrodesmus falcatus using different methods. Rend. Fis. Acc. Lincei 27: 589-595. https://doi.org/10.1007/s12210-016-0528-4

35. Fakas S, Panayotou MG, Papanikolaou S, Komaitis M, Aggelis G (2007) Compositional shifts in lipid fractions during lipid turnover in Cunninghamella echinulata. Enzyme and Microbial Technology 40: 1321-1327.

36. Farias FA, Souza GA, Souza BV, Segundo FP, Silva HL, Cordeiro MT (2018) Selection of Lipid-Producing Fungi Present in Fruits of the Amazon Region. Chemical Engineering Transactions, 64.

37. Gadallah AE, Abd-El-Haleem D (2014) Promising oleaginous filamentous fungi as biodiesel stocks: Screening and Identification. European Journal of Experimental Biology 4(1): 576-582.

38. Hamouda RA, Sherif SA, Dawoud GTM, Ghareeb MM (2016). Enhancement of bioethanol production from Ulva fasciata by biological and chemical saccharification. Rend. Fis. Acc. Lincei 27, 665-672 https://doi.org/10.1007/s12210-016-0546-2

39. Hoekman SK, Broch A, Robbins C, Ceniceros E, Natarajan M (2012) Review of Biodiesel Composition, Properties, and Specifications. Renewable \& Sustainable Energy Reviews 16: 143-169.

40. Hoffmeister D, Keller NP (2007) Natural products of filamentous fungi: enzymes, genes, and their regulation. Natural Product Reports 24: 393-416.

41. Hu C, Zhao X, Zhao J, Wu S, Zhao ZK (2009) Effects of biomass hydrolysis by-products on oleaginous yeast Rhodosporidium toruloides. Bioresource Technology 100: 4843-4847.

42. Huang C, Zong M, Wu H, Liu Q (2009) Microbial oil production from rice straw hydrolysate by Trichosporon fermentans. Bioresource Technology 100: 4535-4538.

43. Hussein AA, El sayed OH, Asker MS, Mohamed SS, Abdelhamid SA (2017) Biodiesel production from local isolate Penicillium commune NRC 2016. Journal of Scientific Research in Science 34: 179-193.

44. Jiru TM, Groenewald M, Pohl C, Steyn L, Kiggundu N, Abate D (2017) Optimization of cultivation conditions for biotechnological production of lipid by Rhodotorula kratochvilovae (syn, Rhodosporidium kratochvilovae) SY89 for biodiesel preparation. Biotech 7: 145-155.

45. Khan AM, Hussain MS (2017) Conversion of wastes to bioelectricity, bioethanol and fertilizer. Water Environment Research 89: 676686.

46. Kirrolia A, Bishnoi NR, Singh R (2012) Effect of shaking, incubation temperature, salinity and media composition on growth traits of green microalgae Chlorococcum sp. Journal of Algal Biomass Utilization 3: 46-53.

47. Knothe G (2008) "Designer" biodiesel: Optimizing fatty ester composition to improve fuel properties. Energy Fuels 19: 1358-1364.

48. Kotasthan T (2017) Potential of microalgae for sustainable biofuel production. Journal of Marine Science: Research \& Development 7: $223-232$. 
49. Kumar I, Ramalakshmi MA, Sivakumar U, Santhanakrishnan P, Zhan X (2011) Production of microbial oils from Mortierella sp. for generation of biodiesel livestock. African Journal of Microbiology Research 5(24): 4105-4111.

50. Kumar SP, Banerjee R (2013) Optimization of lipid enriched biomass production from oleaginous fungus using response surface methodology. Indian Journal of Experimental Biology 51: 979-983.

51. Larone D (2002) Medically important fungi: a guide to identification, $4^{\text {th }}$ ed. ASM Press, Washington (DC).

52. Li Q, Du W, Liu D (2008) Perspectives of microbial oils for biodiesel production. Applied Microbiology and Biotechnology 80: 749756.

53. Magdum S, Minde G, Adhyapak U, Kalyanraman V (2015) Competence evaluation of mycodiesel production by oleaginous fungal strains: Mucor circinelloides and Gliocladium roseum. International Journal of Energy and Environment 6(4): $377-382$.

54. Mahlia TM, Syazmi ZA, Mofijur M, Abas AE, Bilad MR, Ong HC, Silitonga AS (2020) Patent landscape review on biodiesel production: Technology updates. Renewable \& Sustainable Energy Reviews 118: 109526.

55. Matsakas L, Giannakou M, Vörös D (2017) Effect of synthetic and natural media on lipid production from Fusarium oxysporum. Electronic Journal of Biotechnology 30: 95-102.

56. Meng X, Yang J, Xu X, Zhang L, Nie Q, Xian M (2009) Biodiesel production from oleaginous microorganisms. Renewable Energy 34(1): 1-5.

57. Minhas AK, Hodgson P, Barrow CJ, Adholeya A (2016) A review on the assessment of stress conditions for simultaneous production of microalgal lipids and carotenoids. Frontiers in Microbiology 7(54): 1-19.

58. Murad A, Karim N, Hashim N, Adnan A, Zainal Z, Hamid A, Bakar F (2010) Identification and characterization of an oleaginous fungus producing high g-Linoleneic acid. International Journal of Microbiology 9: 1-9.

59. Nisar J, Razaq R, Farooq M, Iqbal M, Khan RA, Sayed M, Shah A, Rahman I (2017) Enhanced biodiesel production from Jatropha oil using calcined waste animal bones as catalyst. Renewable Energy 101: 111-119.

60. Ochsenreither K, Glück C, Stressler T, Fischer L, Syldatk C (2016) Production strategies and applications of microbial single cell oils. Frontiers in Microbiology 7: 1539.

61. Pandey A, Soccol CR, Mitchell D (2000) New developments in solid state fermentation: I-bioprocesses and products. Process Biochemistry 35: 1153-1169.

62. Papanikolaou S (2012) Oleaginous Yeasts: Biochemical Events Related with Lipid Synthesis and Potential Biotechnological Applications. Fermentation Technology 1: 1-3.

63. Papanikolaou S (2019) Sources of microbial oils with emphasis to Mortierella (Umbelopsis) isabellinafungus. World Journal of Microbiology and Biotechnology 35: 63.

64. Papanikolaou S, Aggelis G (2002) Lipid production by Yarrowia lipolytica growing on industrial glycerol in a single-stage continuous culture. Bioresource Technology 82: 43-49.

65. Papanikolaou S, Aggelis G (2011) Lipids of oleaginous yeasts. Part I: Biochemistry of single cell oil production. European Journal of Lipid Science and Technology 113: 1031-1051.

66. Park WS, Murphy PA, Glatz BA (1990) Lipid metabolism and cell composition of the oleaginous yeast Apiotrichum curvatum grown at different carbon to nitrogen ratios. Canadian Journal of Microbiology 36: 318-326.

67. Patel A, Arora N, Mehtani J, Pruthi V, Pruthi A (2017) Assessment of fuel properties on the basis of fatty acid profiles of oleaginous yeast for potential biodiesel production. Renewable and Sustainable Energy Reviews 77: 604-616.

68. Patel P, Desai R (2019) Study of cellulase by isolated fungal culture from natural resources and application in bio-ethanol production. International Journal of Applied Science and Technology 7(3): 2277-2285.

69. Peng X, Chen H (2008) Single cell oil production in solid-state fermentation by Microsphaeropsis sp. from steam-exploded wheat straw mixed with wheat bran. Bioresource Technology 99 (9): 3885-3889.

70. Polburee P, Yongmanitchai W, Lertwattanasakul N, Ohashi T, Fujiyama K, Limtong S (2015) Characterization of oleaginous yeasts accumulating high levels of lipid when cultivated in glycerol and their potential for lipid production from biodiesel-derived crude glycerol. Fungal Biology 119: 1194-1204.

71. Qiao W, Tao J, Luo Y, Tang T, Miao J, Yang Q (2018) Microbial oil production from solid-state fermentation by a newly isolated oleaginous fungus, Mucor circinelloides Q531 from mulberry branches. Royal Society Open Science 5(11): 180551.

72. Radwan SS (1978) Coupling of Two-Dimensional Thin-Layer Chromatography with Gas Chromatography for the Quantitative Analysis of Lipid Classes and their Constituent Fatty Acids. Journal of Chromatographic Science 16 (11): $538-542$.

Page $12 / 19$ 
73. Ramírez-Castrillón M, Jaramillo-Garcia VP, Rosa PD, Landell MF, Vu D, Fabricio MF, Ayub MA, Robert V, Henriques JA, Valente P (2017) The oleaginous yeast Meyerozyma guilliermondii BI281A as a new potential biodiesel feedstock: selection and lipid production optimization. Frontiers in microbiology 8: 1776.

74. Ratledge C (2013) Microbial oils: An introductory overview of current status and future prospects. OCL 20(6): D602.

75. Reis CER, Carvalho AKF, Bento HBS, De Castro HF (2019) Integration of microbial biodiesel and bioethanol industries through utilization of vinasse as substrate for oleaginous fungi. Bioresource Technology Reports 6: 46-45.

76. Rivaldi JD, Carvalho AKF, da Conceição LRV, de Castro HF (2017) Assessing the Potential of Fatty Acids Produced by Filamentous Fungi as Feedstock for Biodiesel Production. Preparative Biochemistry \& Biotechnology 47(10): 970-976.

77. Rossi M, Amaretti A, Raimondi S, Leonardi A (2011) Getting lipids for biodiesel production from oleaginous fungi. In: Stoytcheva M (ed). Biodiesel - Feedstocks and Processing Technologies. Intech, pp. 72-92

78. Ruan Z, Zanotti M, Archer S, Liao W, Liu Y (2014) Oleaginous fungal lipid fermentation on combined acid- and alkali-pretreated corn stover hydrolysate for advanced biofuel production. Bioresource Technology 163: 12-17.

79. Rude MA, Schirmer A (2009) New microbial fuels: a biotech perspective. Current Opinion in Microbiology 12: 274-281.

80. Saxena V, Sharma C, Bhagat S, Saini V, Adhikari D (2008) Lipid and fatty acid biosynthesis by Rhodotorula minuta. Journal of the American Oil Chemists Society 75: 501-505.

81. Shafiq AS, Ali HR (2017) Myco-diesel production by oleaginous fungi. Research Journal of Pharmaceutical, Biological and Chemical Sciences 8(2): 1252-1259.

82. Shafiq S, Chechan R (2019) Influence of different natural media on production of myco-diesel. Earth and Environmental Science 388: 1-7.

83. Shafiq Sh (2017) Biodiesel production by oleaginous fungi before and after exposing of U.V. light. International Journal of ChemTech Research 10 (12): 357-363.

84. Sitepu IR, Garay LA, Sestric R, Levin D, Block DE, German JB, Boundy-Mills KL (2014) Oleaginous yeasts for biodiesel: Current and future trends in biology and production. Biotechnology Advances 32: 1336-1360.

85. Somasekhar D, Venkateshwaran G, Sambaiah K, Lokesh BR (2003) Effect of Culture Conditions on Lipid and Gamma-Linoleic Acid Production by Mucoraceous Fungi. Process Biochemistry 38: 1719-1724.

86. Subhash GV, Mohan SV (2011) Biodiesel production from isolated oleaginous fungi Aspergillus sp. using corncob waste liquor as a substrate. Bioresource Technology 102(19): 9286-9290.

87. Subhash GV, Mohan SV (2014) Lipid accumulation for biodiesel production by oleaginous fungus Aspergillus awamori: Influence of critical factors. Fuel 116: 509-515.

88. Subramaniam R, Stephen D, Mark Z, Rakesh B (2010) Microbial lipids from renewable resources: production and characterization.Journal of Industrial Microbiology \& Biotechnology 37(12): 1271-1287.

89. Sukrutha S, Adamechova K, Savitha J, Certik M (2014) Optimization of Physiological Growth Conditions for Maximal Gammalinolenic Acid Production by Cunninghamella blakesleeana JSK2. Journal of the American Oil Chemists' Society 91: 1507-1513.

90. Tao J, Dai CC, Dai Q (2006) The conversion efficiency and economic feasibility of microbial energy. Chinese Journal of Microbiology 26:48-54.

91. Tsegaye B, Balomajumder C, Roy P (2018a) Biodegradation of wheat straw by Ochrobactrum oryzae BMP03 and Bacillus sp. BMP01 bacteria to enhance biofuel production by increasing total reducing sugars yield. Environmental Science and Pollution Research 25: 30585-30596.

92. Tsegaye B, Balomajumder C, Roy P (2018b) Biodelignification and hydrolysis of rice straw by novel bacteria isolated from wood feeding termite. Biotech 8: 447-458.

93. Vicente G, Bautista LF, Rosalía Rodríguez R, Gutiérrez F (2009) Biodiesel production from biomass of an oleaginous fungus. Biochemical Engineering Journal 48(1): 22-27.

94. Vieira JP, lenczak JL, Rossell CE, Pradella JG, Franco TT (2014) Microbial lipid production: screening with yeasts grown on Brazilian molasses. Biotechnology Letters 36: 2433-2442.

95. Vyas S, Chhabra M (2017) Isolation, identification and characterization of Cystobasidium oligophagum JRC1: a cellulose and lipase producing oleaginous yeast. Bioresource Technology223: 250-258.

96. White TJ, Bruns T, Lee S, Taylor J (1990) Amplification and direct sequencing of fungal ribosomal RNA genes for phylogenetics. In: Innis MA, Gelfand DH, Sninsky JJ, White TJ (eds). PCR Protocols: A guide to Methods and Applications. Academic Press, San Diego,

Page $13 / 19$ 
U.S.A., pp.315-322.

97. Wormslev EC (2016) Sustainable jet fuel for aviation: Nordic perpectives on the use of advanced sustainable jet fuel for aviation. Nordic Council of Ministers, Swedish.

98. Wu S, Hu C, Jin G, Zhao X, Zhao ZK (2010) Phosphate-limitation mediated lipid production by Rhodosporidium toruloides. Bioresource Technology 101(15): 6124-6129.

99. Xing D, Wang H, Pan A, Wang J, Xue D (2012) Assimilation of corn fiber hydrolysates and lipid accumulation by Mortierella isabellina. Biomass Bioenergy 39: 494-501.

100. Yousuf A, Sannino F, Addorisio V, Pirozzi D (2010) Microbial conversion of olive oil mill wastewaters into lipids suitable for biodiesel production. Journal of Agricultural and Food Chemistry 58: 8630-8635.

101. Zhao X, Kong X, Hua Y, Feng B, Zhao Z (2008) Medium optimization for lipid production through co-fermentation of glucose and xylose by the oleaginous yeast Lipomyces starkeyi. European Journal of Lipid Science and Technology 110(5): 405-412.

102. Zheng Y, Yu X, Zeng J, Chen S (2012) Feasibility of filamentous fungi for biofuel production using hydrolysate from dilute sulfuric acid pretreatment of wheat straw. Biotechnology for Biofuels 5: 50 .

103. Ziino M, Curto RL, Salvo F, Signorino D, Chiofalo B, Giuffrida D (1999) Lipid composition of Geotrichum candidum single cell protein grown in continuous submerged culture. Bioresource Technology 67(1): 7-11.

\section{Figures}

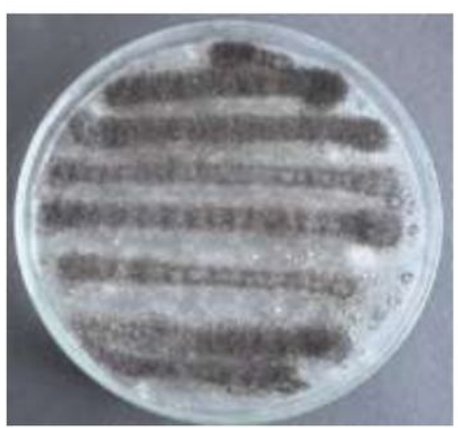

A1

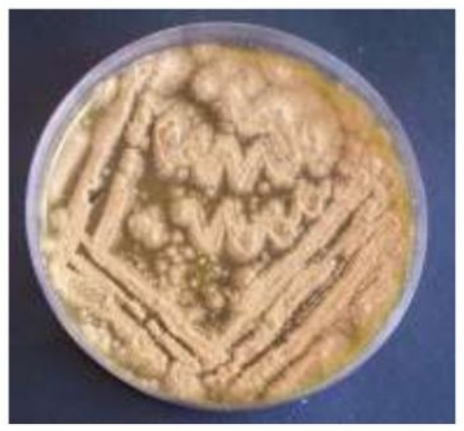

A2

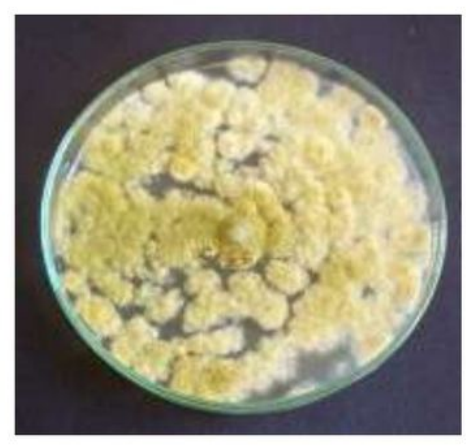

A3

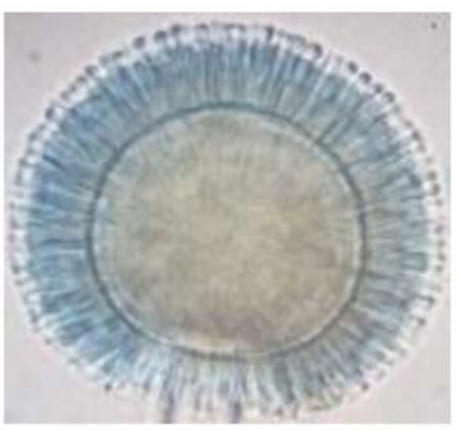

B1

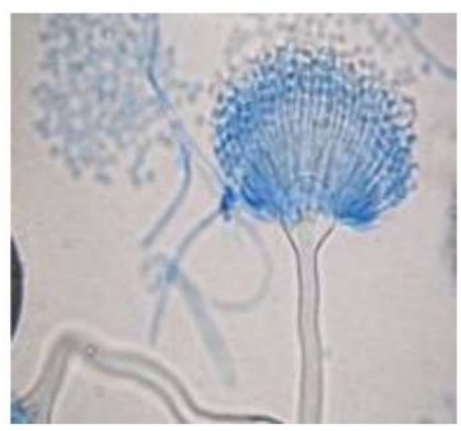

B2

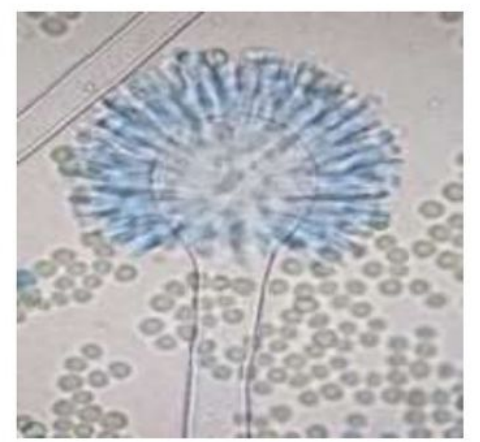

B3 


\section{Figure 1}

Oleaginous fungi (A) in PDA medium and (B) on microscopy with magnification of 1000x: (ARS- A1) A. niger, (ARS-A2) A. terreus, and (ARSA-3) A. flavus.

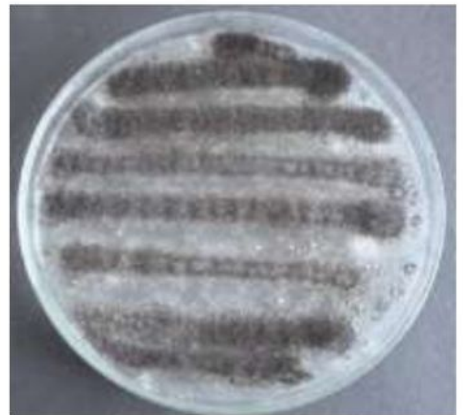

A1

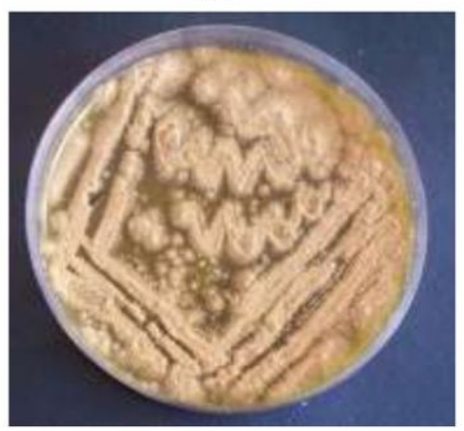

A2

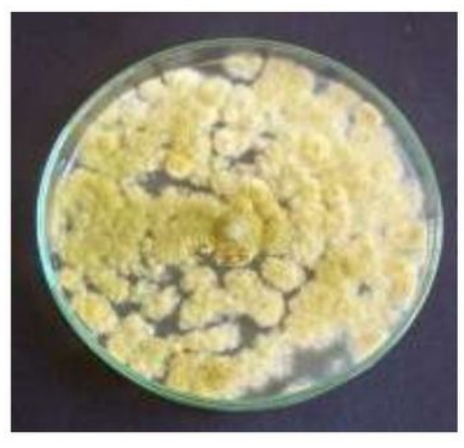

A3

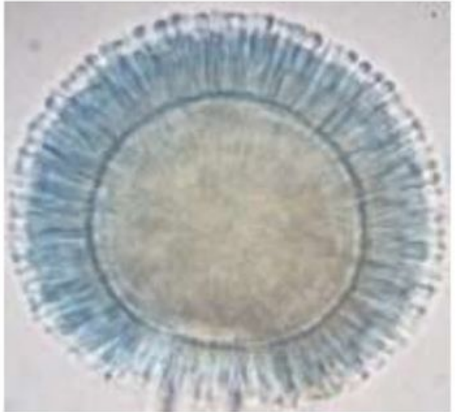

B1

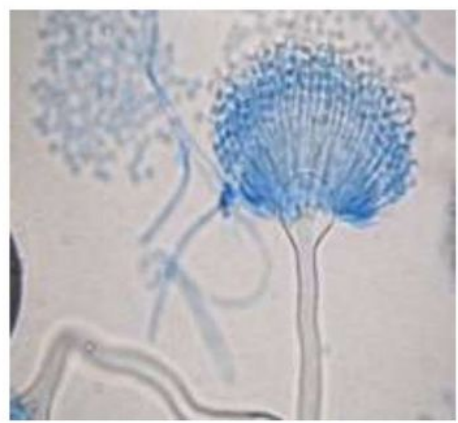

B2

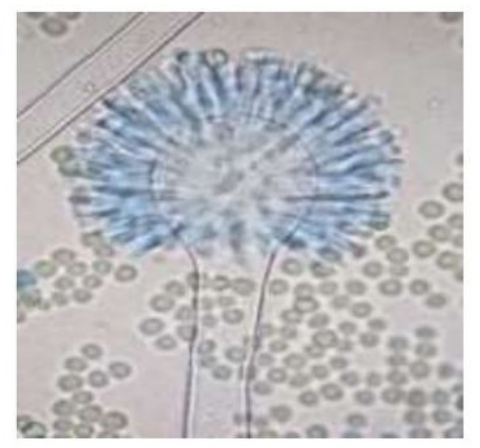

B3

\section{Figure 1}

Oleaginous fungi (A) in PDA medium and (B) on microscopy with magnification of 1000x: (ARS- A1) A. niger, (ARS-A2) A. terreus, and (ARSA-3) A. flavus. 


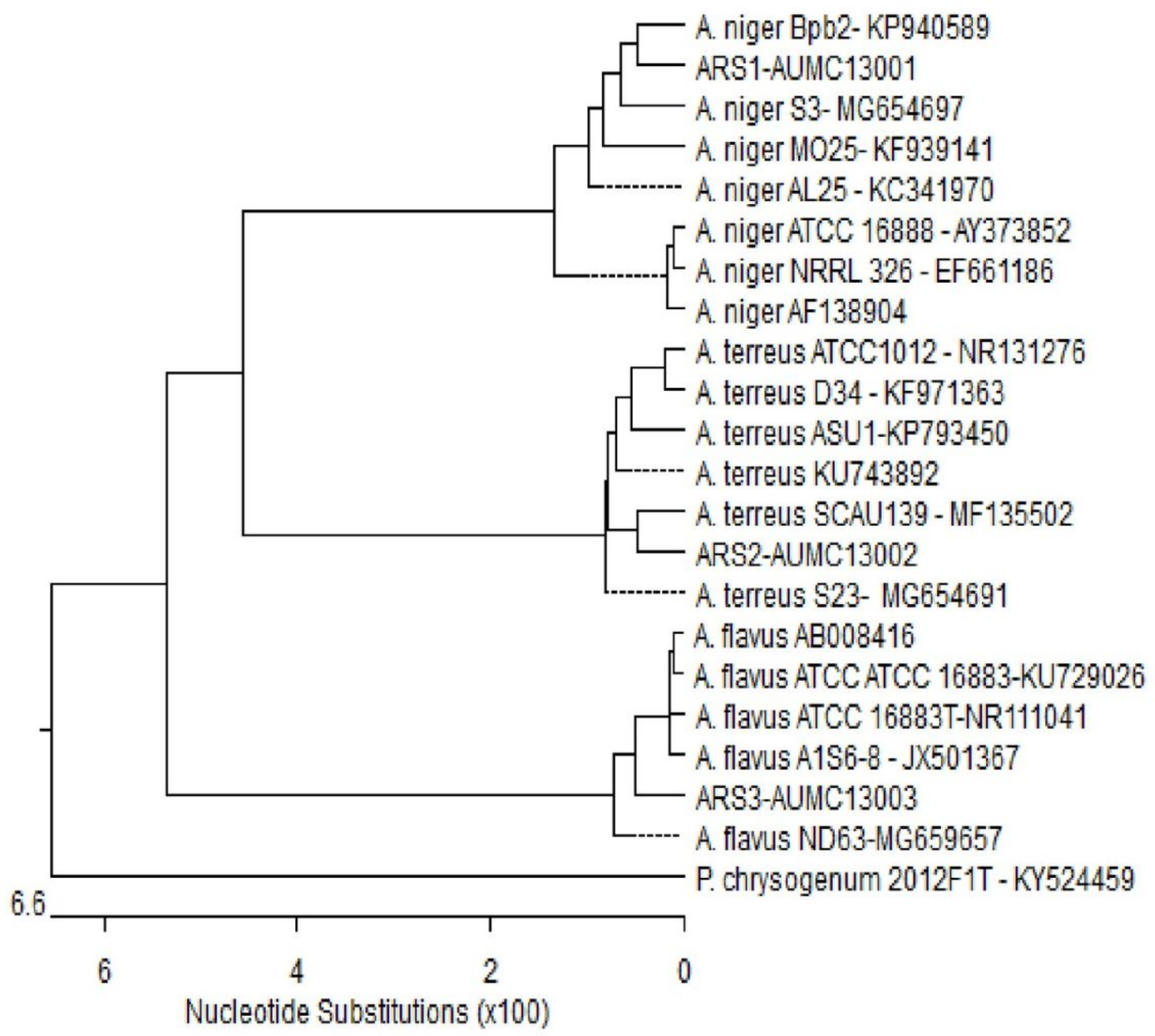

Figure 2

Phylogenetic tree of 18 S rRNA sequences of fungal strains (ARS-1, ARS-2, and ARS-3) aligned with closely related sequences accessed from the GenBank. (A.= Aspergillus, P.= Penicillium) P. chrysogenum was included as out-group strain. 


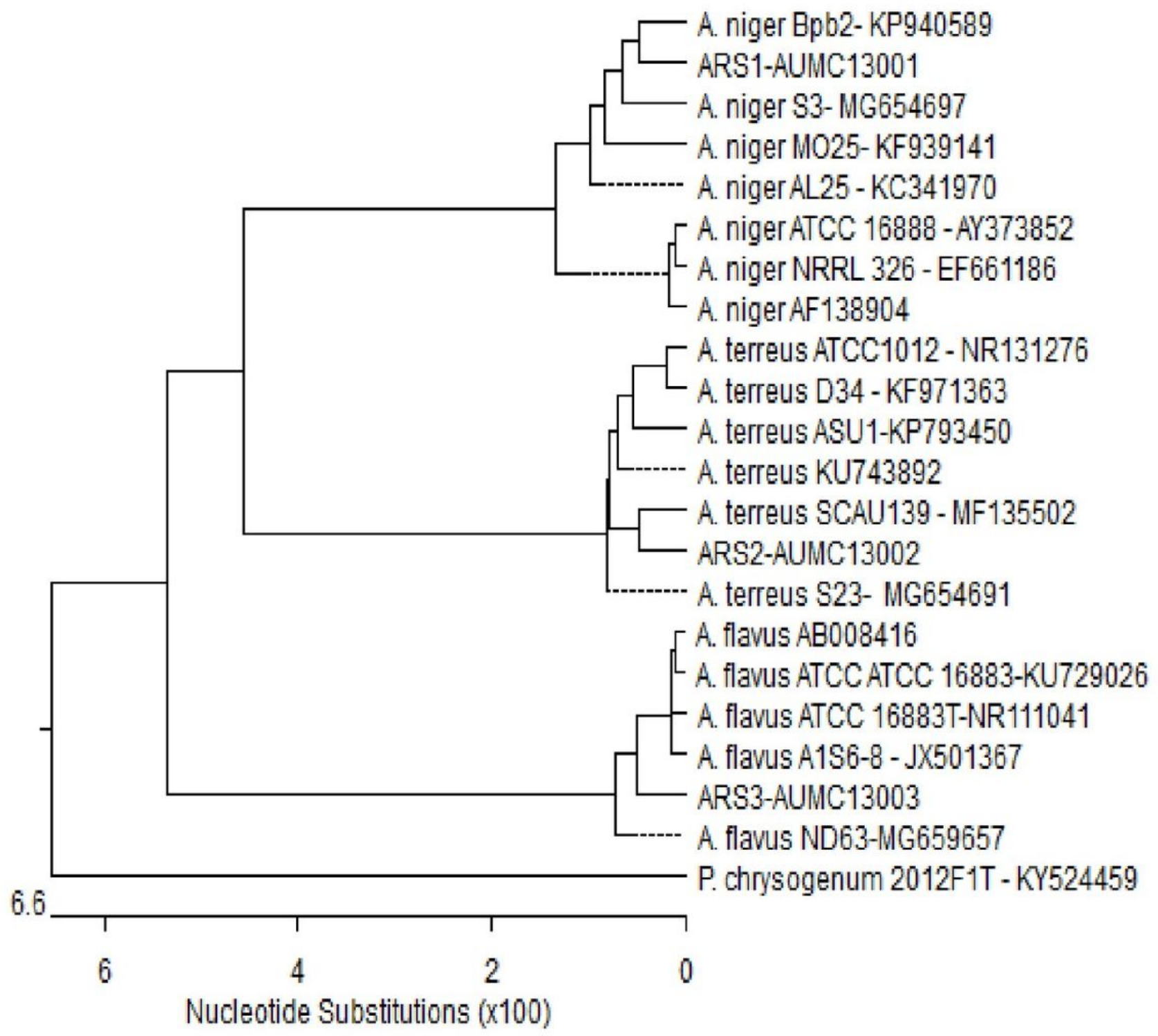

Figure 2

Phylogenetic tree of 18 S rRNA sequences of fungal strains (ARS-1, ARS-2, and ARS-3) aligned with closely related sequences accessed from the GenBank. (A.= Aspergillus, P.= Penicillium) P. chrysogenum was included as out-group strain. 


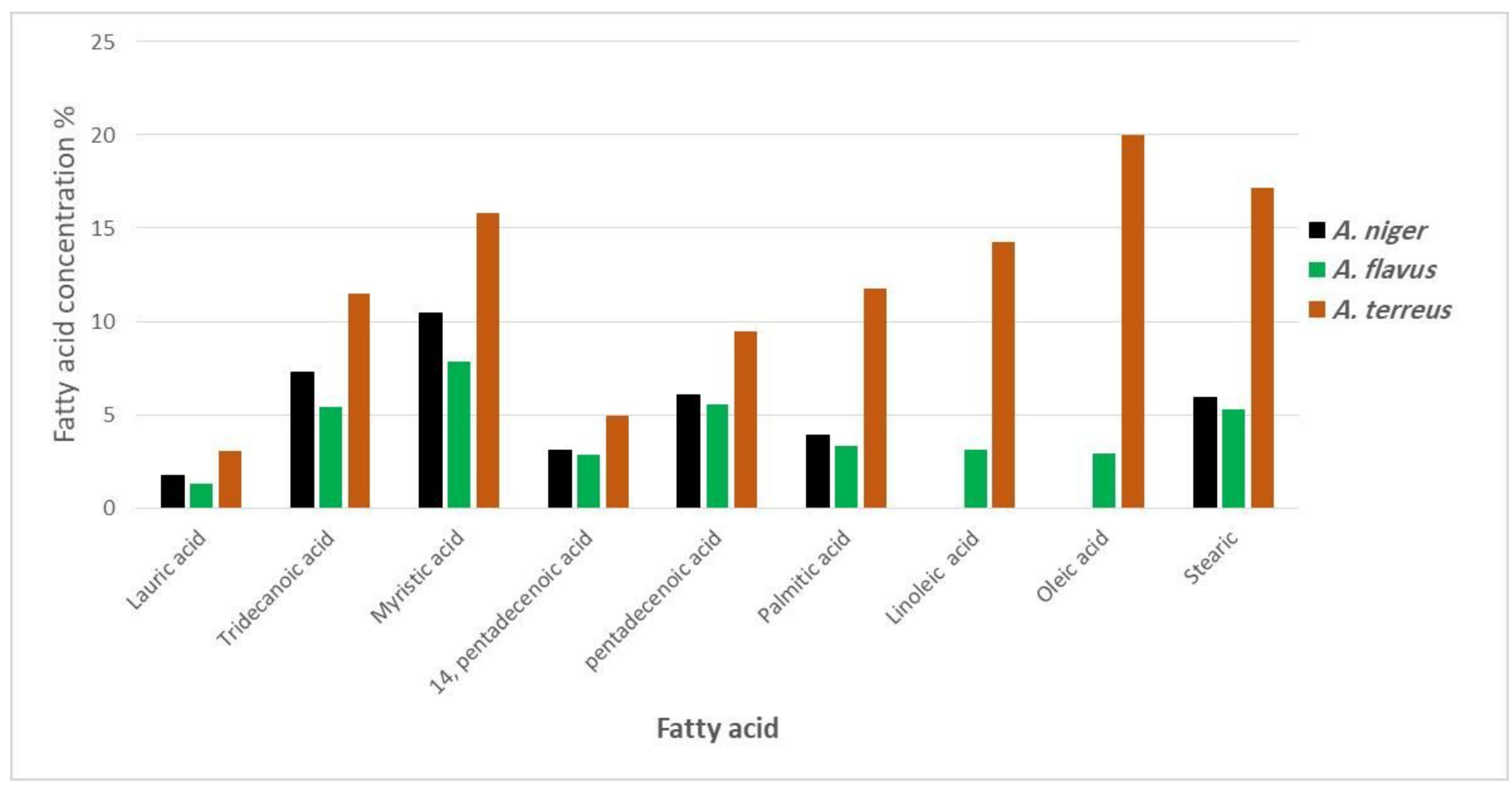

\section{Figure 3}

Gas chromatography - profile of fungal FAME promising strains.

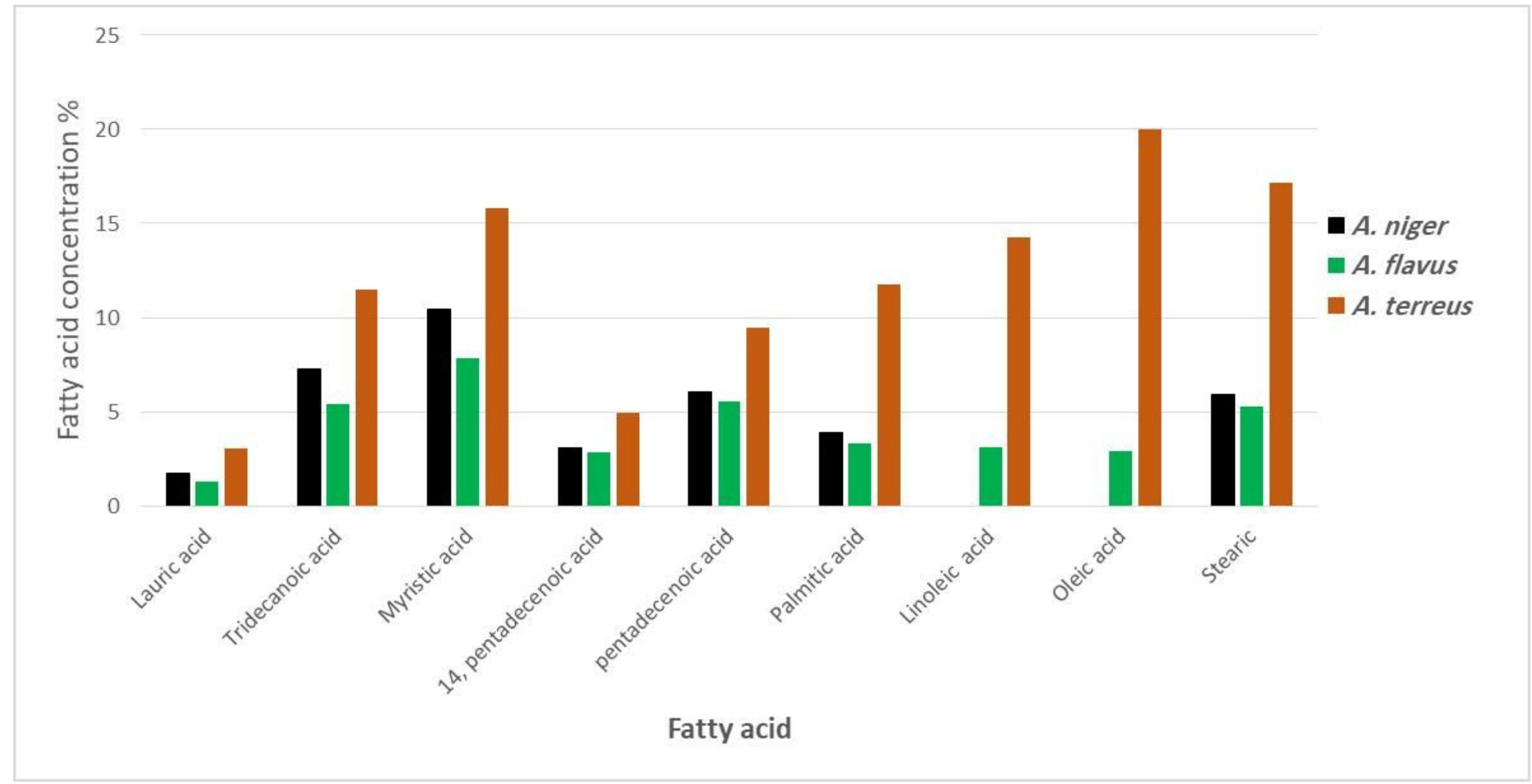

\section{Figure 3}

Gas chromatography - profile of fungal FAME promising strains. 


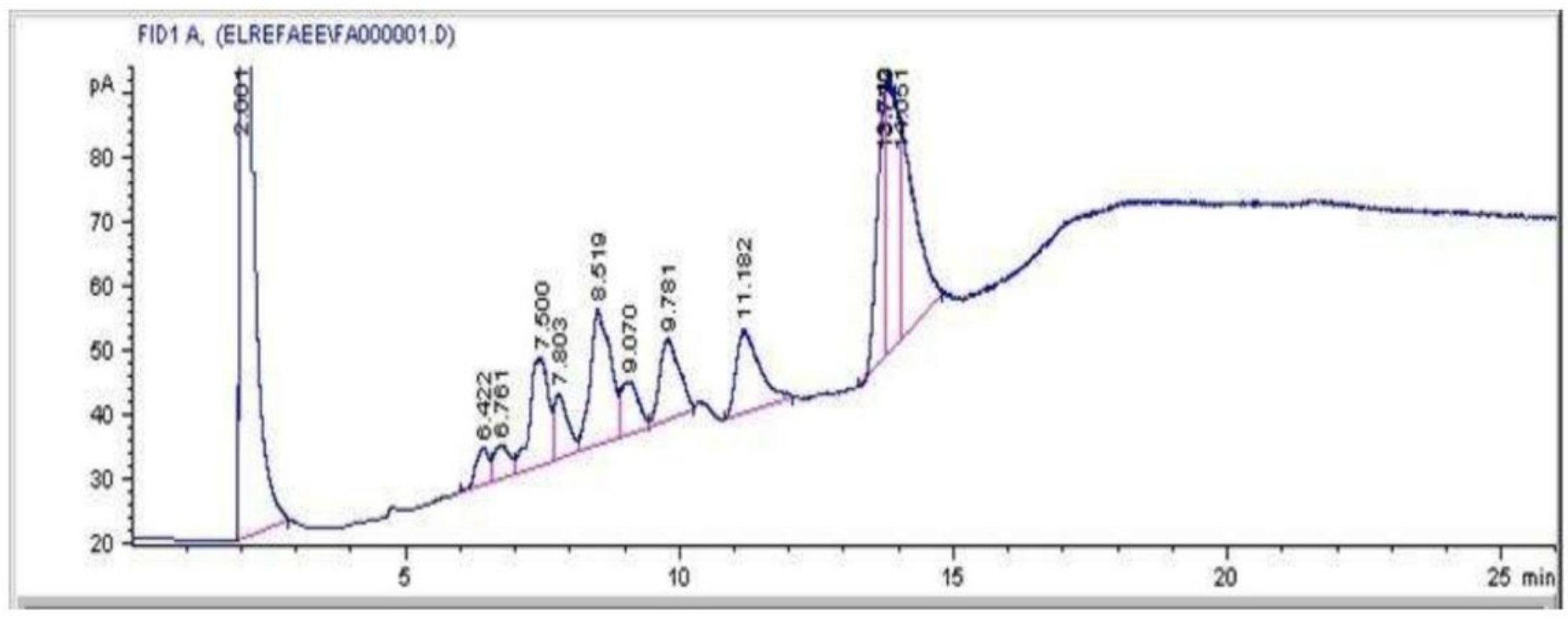

Figure 4

Gas chromatography-profile analysis of Aspergillus terreus methyl esters

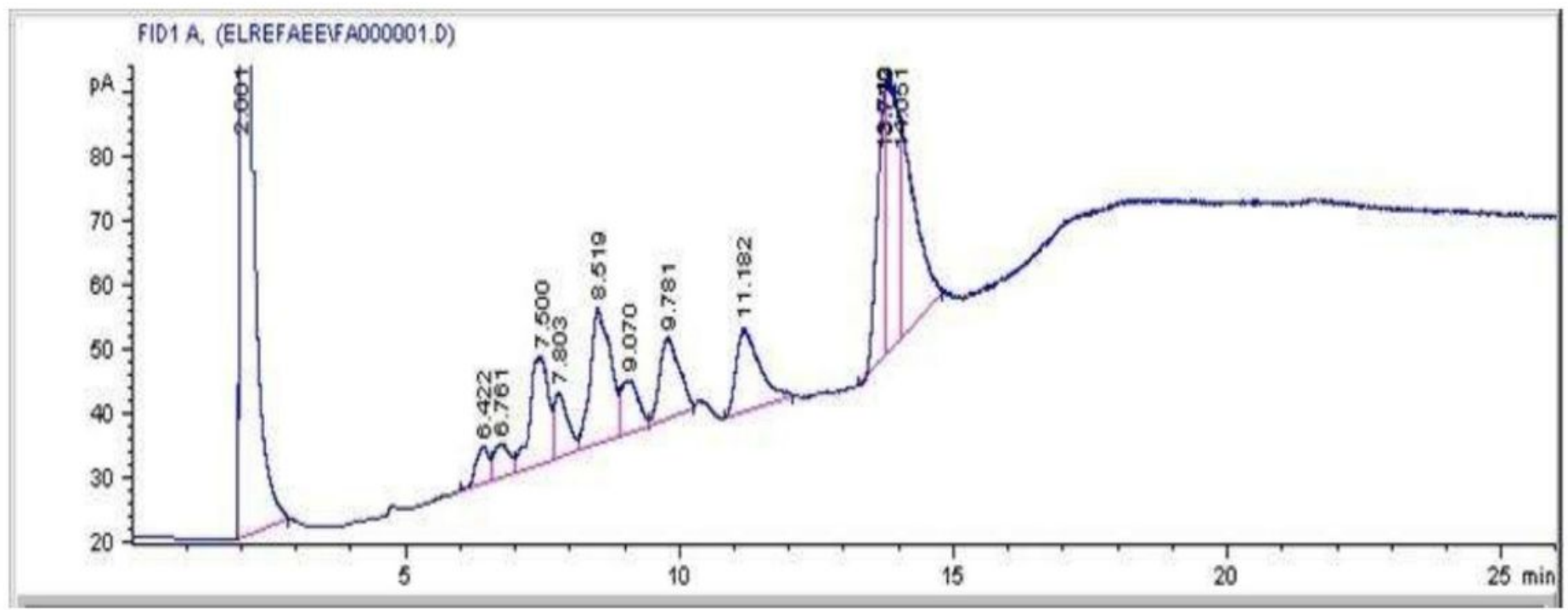

Figure 4

Gas chromatography-profile analysis of Aspergillus terreus methyl esters

\section{Supplementary Files}

This is a list of supplementary files associated with this preprint. Click to download.

- graphicalabstractJPEG.jpg

- graphicalabstractJPEG.jpg 